\title{
THE EFFECT OF TOMAN (Chana micropetes) EXTRACT ON THE IMPROVEMENT OF ALBUMIN LEVELS IN MENCIT/MICE (Mus musculus)
}

\author{
Pipit Festi Wiliyanarti ${ }^{1}$ Aisyah Dia Maulida ${ }^{2}$ \\ 1,2 Department of Community Nursing S1 Study Program \\ Faculty of Health Sciences Univ. Muhammadiya Surabaya \\ E-mail: pipitfesti.um-surabaya.ac.id
}

\begin{abstract}
Tanggal Submit:

26 Agustus 2020

Tanggal Review:

5 November 2020

Tanggal Publish

Online:

20 Desember 2020

Hypoalbuminemia is a condition in which albumin levels are less than $3.8 \mathrm{~g} / \mathrm{dl}$. Management of hypoalbumin can be done on a high high in protein such as toman fish extract (Chana Micropetes). Toman fish extract contains globular protein which can be used as an alternative diet in increasing albumin levels. The purpose of this study was to determine the effect of toman fish extract on increasing albumin levels in mencit (Mus musculus).

This research is an experimental research design with Pretest-Posttest Control Group Design. Samples using Mus musculus with the criteria of male sex, body weight 25-40 grm and 2 months old. The number of samples consisted of 32 animals consisting of 2 groups, 16 control groups and 16 treatment groups. Intervention by giving toman fish extract for 14 days. Research instruments, albumin levels and observation sheets. Data were tested statistically with Independent Sample t Test.

The results, this study showed the average value of albumin levels was $5.60 \mathrm{gr} / \mathrm{dl}$ in the treatment group so that an increase in albumin levels. There was a significant effect ( $p$ $=0,000<\alpha=0.05$ ) between the administration of toman fish extract to the increase in albumin levels in mencit (Mus Muculus).

Conclusion, giving toman fish extract can increase albumin levels in mencit. So that toman fish extract can be used as a high-protein alternative diet for hypoalbumin sufferers.

Keywords: hypoalbumin, toman fish, (Chana Micropetes)
\end{abstract}

\section{INTRODUCTION}

Decrease in albumin levels is a condition in which albumin levels are less than $3.8 \mathrm{~g} / \mathrm{dl}$ which is also called hypoabuminemia, in this condition physiological processes often occur in the body, especially in patients who are seriously ill so that they can interfere with and hinder the healing process and recovery (Gatta, 2012). At present, administration of serum albumin is one of the treatments in hypoabuminemia, administration of serum abumin in clinical settings continues to be a 
consideration because its use requires a relatively high cost.

At present, restrictions on use are based on the severity or low levels of the patient's albumin (Ackland, 2013). The limited use of albumin in the packaging is also a matter that needs to be considered as well. The use of serum albumin must pay attention to the duration of albumin, which should not be more than 4 hours after the package is opened. Because it is related to the stability of available albumin which must be used for 4 hours because it is easily coagulated by heat (Syarifah, 2015). So it is very necessary alternative food ingredients that contain high albumin as an alternative management of hypoalbuminemia.

The prevalence of kidney failure with hypoalbumin in Indonesia amounted to $100-150$ per 1 million population in 2014. According to the East Java Provincial Health Office the incidence of malnutrition accompanied by hypoalbumin in 2015-2016 reached 1.8 percent or 10 percent of the total population of around 37, 47 million inhabitants. Whereas the data of RSUD Dr. Soetomo Surabaya in 2016-2017 the incidence of CKD accompanied by hypoalbumin totaled 453 people.

Decreased levels of albumin in the blood are also a complication of kidney failure. This can be caused by the conduction of proteinuria, uremia, and the synthesis of amino acids in our body. Food intake and nutritional status can influence serum albumin levels in patients with kidney disease, because albumin synthesis is closely related to amino acids produced by the liver, when the rate of synthesis decreases due to malnutrition, there is a decrease in albumin in circulation, causing albumin transfer. Malnutrition is a common condition that occurs in patients with advanced renal failure (stage 4-5). Malnutrition in patients with kidney failure is caused due to insufficient food intake caused by protein retriction as an intervention step to inhibit progression in kidney failure patients. In addition, the decrease in GFR, renal excretion function will be disrupted and cause uremia so that there will be a buildup of toxic metabolic which interferes with the work of the liver. The liver is unable to compensate for the loss of albumin in the blood and decreased levels of albmin in the circulation which will cause edema (Ackland, 2013).

Albumin is a protein in human plasma that dissolves in water and settles in heating. As for the function of albumin, maintaining omkotic pressure, carrying thyroid hormones, fatty acids, bilirubin, drugs and as an acute negative inflammatory protein, as an immune response. Albumin can be lost from the 
blood through the excretion tool, especially in the kidneys. In some kidney diseases, such as inflammation of glomelurus, nephrotic syndrome occurs leak albumin through the pores of the basement membrane of the glomerulus.

Supposedly, this membrane cannot be penetrated by albumin, because the pores are smaller than the size of this protein molecule, in kidney disease, albumin can escape through the pore hole and come out with urine. As a result, in addition to experiencing hypoalbuminemia, also will experience albuminoria (Guyton, and Hall, 2016).

As for several ways that can increase albumin levels in blood in patients with hypoalbumin, including parenterally and peroral albumin supplements, parenteral administration such as serum albumin, serum albumin therapy which is usually given to patients with chronic kidney disease when patients have hypoalbumin with albumin levels <2, $5 \mathrm{~g} / \mathrm{dl}$ (Ackland, 2013).

The use of animals or parts of animals is one of the alternative ingredients in medical therapy that has not yet developed, even though in terms of natural resources, especially Indonesian waters, it is very potential if it is developed into a source of material in medical therapy. Utilization of marine animals and river animals as treatment materials is currently still in the development stage, for example the use of fish as therapeutic agents. In toman fish (Chana micropeltes) The content contained in toman fish is omega 3 with EPA $0.32 \%$ body weight and DHA $1.43 \%$ body weight and omega 9 $10.33 \%$ body weight, if added to the total fatty acids contained in Toman fish meat is $63.08 \% \mathrm{BB}$. And amino acid content in toman fish $18.89 \%$ (Singgih, (2012).

The use of extract that has been done by many studies is to use cork fish (ikan gabus). Research Tests on the healing effect of cut wounds in male rats have been conducted and given toman fish extract at a dose of $15.7 \mathrm{~mL} / \mathrm{kg}$ $\mathrm{BW}$ of rats in the first and second groups at a dose of $3.7 \mathrm{~mL} / \mathrm{kg} \mathrm{BW}$ of rats for 14 days, based on tests conducted there is a significant effect between albumin levels and wound healing (Irwanda, 2015). Some studies explain albumin levels are very influential on how fish are extracted. The content of toman fish extract based on research by Fitriyani \& Deviarni (2018) protein 53, 14\%, 8.45\% fat content, $8.04 \%$ water content $8.36 \%$ ash content, carbohydrate content $21.98 \%$ $\mathrm{Zn}$ content $0.33 \% \mathrm{mg} / \mathrm{L}$.

Based on the description above, it is necessary to study the effect of giving the extract of Toman fish (Chana 
micropeltes) to increase albumin levels in menci (Mus musculus). The existence of a study about the administration of this extract is an alternative to increase albumin levels in patients with hypo albumin.

\section{RESEARCH METHODS}

This type of research is experimental with a Pretest-Posttest Control Group Design research (Nursalam, 2017). The study was conducted in the laboratory of the Mipa Faculty of Airlangga University, East Java. Mencit (Mus musculus) that are used are in IKHP (Experimental Animal Cage Installation). The samples in this study were 32 male mencit (Mus musculus) which were divided into 2 groups of 16 treatment groups, 16 control groups. The selection of experimental animals is that which meets healthy criteria, male sex, body weight 25-40 grm and 2 months old (Kusumawati, 2009).

The experimental implementation consisted of control group A and treatment $B$ given standard feed and drinking water, after the adaptation period, then the mencit were satisfied for 2 hours before the pretest measurement of albumin levels in both groups, then the group would be terminated to take blood samples. After examination of albumin levels in both groups, the treatment group was given toman fish extract at a dose of $3.7 \mathrm{ml} /$

$\mathrm{kg} \mathrm{BW}$ of mencit per day for 14 days.

On the 14th day the mencit were fasted for 2 hours, then the group would be terminated to take peripheral blood samples through the abdominal aorta. The material used was Toman fish (Chana micropeltes) $3.7 \mathrm{~mL}$ toman fish extract / Kg body weight Mencit.

The measuring instrument used was the observation sheet and the albumin content measuring instrument brow crosel green (BCG) method. Measurement of albumin levels was carried out at the Surabaya Farma Veterinary Center conducted on day 1 and after day 14. The examination test followed the national standard (SNI, 2006). The criteria for examination results were categorized, Hypoalbumin $2.5-3.7$ gr $/$ dl. $2=$ normal albumin 3,8 - $5.5 \mathrm{gr} / \mathrm{dl}$. The results of the study are in the form of data and tabulations to determine the effect of toman fish extract on increasing albumin levels in mencit. Statistical analysis was performed normality test and different test using independent $\mathrm{t}$ test. This study has obtained an ethics test permit at the Ethics Commission of the Nahdatul Ulama University in Surabaya in 2019.

\section{RESULTS}

Results Observation of albumin levels of mencit before administration of toman 
fish extract (Chana micropeltes) in the control and treatment groups

1. Albumin levels of mencit (Mus muculus) in the control and treatment groups before the interventio

Table 1. Albumin levels of mencit in the control and treatmen group before the intervention

\begin{tabular}{|c|c|c|c|c|c|}
\hline Number & $\begin{array}{l}\text { albumin } \\
\text { level } \\
\text { control } \\
\text { group }\end{array}$ & category & Number & $\begin{array}{l}\text { albumin } \\
\text { level } \\
\text { intervention } \\
\text { group }\end{array}$ & category \\
\hline 1 & 3,1 & Hipoalbumin & 1 & 3,5 & Hipoalbumin \\
\hline 2 & 4,0 & $\begin{array}{l}\text { Albumin } \\
\text { Normal }\end{array}$ & 2 & 3,3 & Hipoalbumin \\
\hline 3 & 2,7 & Hipoalbumin & 3 & 3,9 & $\begin{array}{l}\text { Albumin } \\
\text { normal }\end{array}$ \\
\hline 4 & 3,6 & Hipoalbumin & 4 & 3,1 & Hipoalbumin \\
\hline 5 & 3,4 & Hipoalbumin & 5 & 3,7 & Hipoalbumin \\
\hline 6 & 3,0 & Hipoalbumin & 6 & 3,3 & Hipoalbumin \\
\hline 7 & 3,2 & Hipoalbumin & 7 & 4,2 & $\begin{array}{l}\text { Albumin } \\
\text { normal }\end{array}$ \\
\hline 8 & 4,0 & $\begin{array}{l}\text { Albumin } \\
\text { Normal }\end{array}$ & 8 & 3,5 & Hipoalbumin \\
\hline 9 & 4,3 & $\begin{array}{l}\text { Albumin } \\
\text { Normal }\end{array}$ & 9 & 3,9 & $\begin{array}{l}\text { Albumin } \\
\text { normal }\end{array}$ \\
\hline 10 & 3,0 & Hipoalbumin & 10 & 4,0 & $\begin{array}{l}\text { Albumin } \\
\text { normal }\end{array}$ \\
\hline 11 & 3,8 & $\begin{array}{l}\text { Albumin } \\
\text { Normal }\end{array}$ & 11 & 3,8 & $\begin{array}{l}\text { Albumin } \\
\text { normal }\end{array}$ \\
\hline 12 & 4,2 & $\begin{array}{l}\text { Albumin } \\
\text { Normal }\end{array}$ & 12 & 4,1 & $\begin{array}{l}\text { Albumin } \\
\text { normal }\end{array}$ \\
\hline 13 & 3,9 & $\begin{array}{l}\text { Albumin } \\
\text { Normal }\end{array}$ & 13 & 4,0 & $\begin{array}{l}\text { Albumin } \\
\text { normal }\end{array}$ \\
\hline 14 & 3,3 & Hipoalbumin & 14 & 3,2 & Hipoalbumin \\
\hline 15 & 4,0 & $\begin{array}{l}\text { Albumin } \\
\text { Normal }\end{array}$ & 15 & 3,7 & Hipoalbumin \\
\hline 16 & 3,5 & Hipoalbumin & 16 & 3,9 & $\begin{array}{l}\text { Albumin } \\
\text { normal }\end{array}$ \\
\hline & average & 3,56 & & average & 3,693 \\
\hline
\end{tabular}

Source:Wiliyanarti, 2019

The results of the albumin levels of mencit in the control group were $3.56 \mathrm{gr} / \mathrm{dl}$ and the albumin levels in the treatment group before giving toman fish extract 3,693. 
2. Observation Results Albumin levels in the control group and treatment group after administration of toman fish extract

Table 2. Albumin levels of mencit in the control and treatmen group before the intervention

\begin{tabular}{|c|c|c|c|c|c|}
\hline No & $\begin{array}{l}\text { Albumin level } \\
\text { (control group) }\end{array}$ & category & No & $\begin{array}{l}\text { Albumin level } \\
\text { (intervention } \\
\text { group) }\end{array}$ & category \\
\hline 1 & 3,9 & $\begin{array}{l}\text { Albumin } \\
\text { normal }\end{array}$ & 1 & 5,7 & $\begin{array}{l}\text { Albumin } \\
\text { Normal }\end{array}$ \\
\hline 2 & 3,4 & Hipoalbumin & 2 & 5,9 & $\begin{array}{l}\text { Albumin } \\
\text { Normal }\end{array}$ \\
\hline 3 & 3,1 & Hipoalbumin & 3 & 4,2 & $\begin{array}{l}\text { Albumin } \\
\text { Normal }\end{array}$ \\
\hline 4 & 3,5 & Hipoalbumin & 4 & 4,8 & $\begin{array}{l}\text { Albumin } \\
\text { Normal }\end{array}$ \\
\hline 5 & 3,6 & Hipoalbumin & 5 & 5,1 & $\begin{array}{l}\text { Albumin } \\
\text { Normal }\end{array}$ \\
\hline 6 & 3,5 & Hipoalbumin & 6 & 5,7 & $\begin{array}{l}\text { Albumin } \\
\text { Normal }\end{array}$ \\
\hline 7 & 4,1 & $\begin{array}{l}\text { Albumin } \\
\text { normal }\end{array}$ & 7 & 5,8 & $\begin{array}{l}\text { Albumin } \\
\text { Normal }\end{array}$ \\
\hline 8 & 3,6 & Hipoalbumin & 8 & 5,9 & $\begin{array}{l}\text { Albumin } \\
\text { Normal }\end{array}$ \\
\hline 9 & 3,3 & Hipoalbumin & 9 & 6,0 & $\begin{array}{l}\text { Albumin } \\
\text { Normal }\end{array}$ \\
\hline 10 & 4,2 & $\begin{array}{l}\text { Albumin } \\
\text { normal }\end{array}$ & 10 & 5,9 & $\begin{array}{l}\text { Albumin } \\
\text { Normal }\end{array}$ \\
\hline 11 & 4,0 & $\begin{array}{l}\text { Albumin } \\
\text { normal }\end{array}$ & 11 & 5,5 & $\begin{array}{l}\text { Albumin } \\
\text { Normal }\end{array}$ \\
\hline 12 & 4,1 & $\begin{array}{l}\text { Albumin } \\
\text { normal }\end{array}$ & 12 & 6,2 & $\begin{array}{l}\text { Albumin } \\
\text { Normal }\end{array}$ \\
\hline 13 & 3,7 & Hipoalbumin & 13 & 5,9 & $\begin{array}{l}\text { Albumin } \\
\text { Normal }\end{array}$ \\
\hline 14 & 3,5 & Hipoalbumin & 14 & 5,6 & $\begin{array}{l}\text { Albumin } \\
\text { Normal }\end{array}$ \\
\hline 15 & 3,6 & Hipoalbumin & 15 & 6,0 & $\begin{array}{l}\text { Albumin } \\
\text { Normal }\end{array}$ \\
\hline 16 & 3,9 & $\begin{array}{l}\text { Albumin } \\
\text { normal }\end{array}$ & 16 & 5,4 & $\begin{array}{l}\text { Albumin } \\
\text { Normal }\end{array}$ \\
\hline
\end{tabular}

Source: Wiliyanarti, 2019

The results of mencit albumin levels after administration of toman fish extract in the control group showed an average of 3.687 after 14 days in the treatment group had a value of $4.856 \mathrm{~g} / \mathrm{dl}$. 
3. Analysis of differences in levels of Albumin Mencit (Mus Muculus) After Giving Toman Fish Extract in the Control and Treatment Group

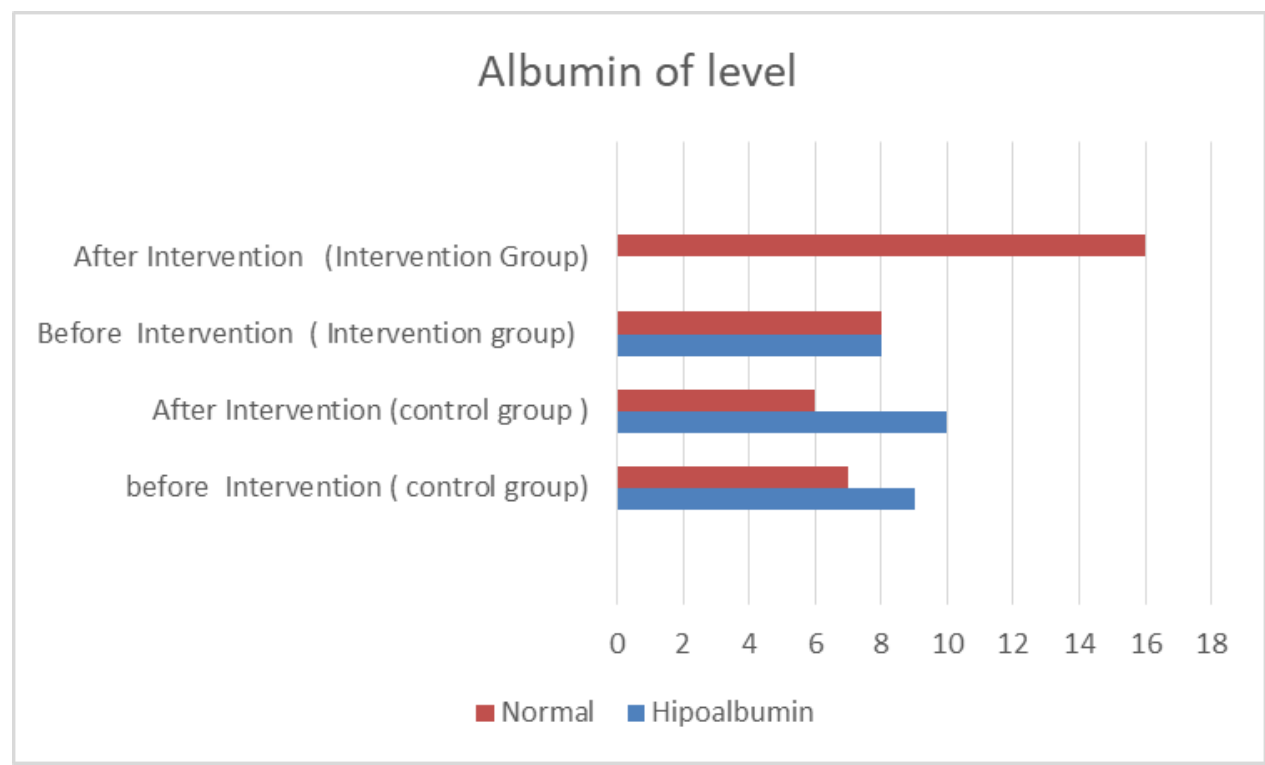

Source: Wiliyanarti, 2019

Figure 1. Comparison of Mice (Mus Muculus) Albumin Levels After Giving Toman Fish Extract in Control and Treatment Groups mice albumin levels after administration of toman fish extract.

Based on the results of the study, most of the serum albumin levels of mice experienced hypoalbumin before giving toman fish extract. After the administration of toman fish extract, most of the albumin levels increased so that the albumin levels were within normal limits. Mice albumin level data before statistical analysis test, normality test will be done first, the results of normality test are normally distributed with $p>0.05$, this can be seen by the significance of the control $(\mathrm{p}=0.599)$ and the treatment $(p=0.09)$. In statistical analysis with the Independent Sample $t$ test, the significance test was $0,000(<0.05)$ so that Ho was rejected. So there is a significant difference between the treatment and control groups.

\section{Discussion}

1. Albumin Levels Before Giving Toman Fish (Chana Micropetes) Extract

The samples used in this study were mice tried animals obtained from Experimental Animal Installations in Pusvetma. After the adaptation period was conducted by the officer. 32 mice were divided into 2 groups, 16 control groups and 16 treatment groups. After that the two groups will be measured albumin levels. The average value of albumin in the control group was (3.68 $\mathrm{gr} / \mathrm{dl}$ ) and the treatment group (3.56 gr / dl) of the average value showed that the albumin level in the treatment group was smaller than the control group.

Based on data obtained from the results of the study, albumin levels before administration of toman fish extracts in the control and treatment groups, mostly in hypoalbumin 
conditions with a total of 8 individuals with a percentage of $50.0 \%$ in the control group and 10 individuals with a percentage of $62.25 \%$ in the treatment group

Albumin is the smallest plasma protein with the most amount, binding and transporting substances that are not soluble in blood, most of the task of albumin is to regulate the balance of plasma colloid osmotic pressure. The molecular weight of albumin is $69 \mathrm{~g} / \mathrm{dl}$ found in the human body, formed from 584 amino acids (Guyton, and Hall, 2016).

Serum albumin levels are determined by the function of the synthesis rate, the rate of degradation and the distribution between the intravascular and extracvascular compartments. Albumin synthesis only occurs in the liver with a formation rate of 12-25 grams / day. Under normal circumstances only $20-30 \%$ of hepatocytes produce albumin. However, this production rate varies depending on the state of the disease and the rate of nutrition because albumin is only formed in the suitable osmotic, hormonal and nutritional environment. The colloidal osmotic pressure of interstitial fluid that wet the hepatocytes is an important regulator of albumin synthesis. Decreased albumin levels or can also be called hypoalbumin is a condition where the level of albumin in the blood drops below normal levels. Normal albumin levels in the blood are 3.8 - $5.5 \mathrm{~g} / \mathrm{dL}$ (Guyton, and Hall, 2016).

Some of these things that can cause a decrease in albumin levels in the blood are physiological stress caused by acute and chronic inflammation, low albumin levels due to acute inflammation and will be normal within a few weeks after the inflammation disappears (Guyton, and Hall, 2016) [4]. The next decrease in albumin is a state of kidney function. Decreased albumin in the blood is a complication of kidney failure. This can be caused by the conduction of proteinuria, uremia, and the synthesis of amino acids in our bodies Gatta, 2012) [1]. Food intake and nutritional status can affect serum albumin levels in patients with kidney disease, because albumin synthesis is closely related to amino acids produced by the liver, when the rate of synthesis decreases due to malnutrition, there is a decrease in albumin in the circulation, which causes the transfer of albumin. In addition, the decrease in GFR, renal excretion function will be disrupted and cause uremia so that there will be a buildup of toxic metabolic which interferes with the work of the liver. The liver is not able to compensate for the loss of albumin in the blood and decreased levels of alumin in circulation which will cause edema (Syarifah, 2015) [3]. Furthermore, decreased albumin levels can be caused by comorbidities because in the process of occurrence of an illness in the body an increase in metabolism so that the intake of nutrients requires more, especially abumin to help the healing process.

\section{Albumin levels after administration} of Toman fish extract (Chana Micropetes)

After measuring albumin levels, the treatment group will be given orally toman fish extract for 14 days at a dose of $3.7 \mathrm{~mL} / \mathrm{kg}$ body weight of mice. When making toman fish extract, from 7 $\mathrm{kg}$ of toman fish meat produced $900 \mathrm{ml}$ of toman fish extract, in the research 
process on day 3 there was 1 mouse in the treatment group that died, indeed trials with experimental animals were given intervention through frequent sonde often cause sore throat, and make the animal try not to survive, so that of the 4 mice in reserve one will replace the position of mice that have fallen. After the extract is given 14 days the mice albumin levels of the mice will be measured again to see the results.

Based on the data obtained from the results of this study, albumin levels after the administration of toman fish extract mostly increased in the number of 16 mice with a percentage of $100 \%$ in the treatment group and 6 with a percentage of $37.5 \%$ in the control group. While 10 mice with a percentage of $62.5 \%$ in the control group experienced hypoalbumin. The average albumin levels obtained in the control group were $(3.67 \mathrm{gr} / \mathrm{dl})$ and the treatment group $(5.60 \mathrm{gr} / \mathrm{dl})$ so that the albumin levels in the treatment group experienced an increase after administration of toman fish extract. In this study, mice that were used as experimental animals were healthy mice, so that in the process of toman fish extract, there were no confounding factors that caused the albumin levels of mice to increase.

As for some ways to increase albumin levels, among others, with oral supplements such as by using a hypoalbumin diet in order to improve and maintain nutritional status. In patients with hypoalbumin given the TKTP diet, if necessary given extra egg whites, extra cork fish, and MPT (Modisco egg whites). Medisco stands for modified Dried Skimmed Milk and Coconut. Medisco is a nutritious food or drink that was first tried on children who experience severe nutritional disorders in Uganda Africa. The most important medical benefits are to overcome malnutrition in humans quickly and easily, so that medical costs become lighter according to Anggraini (2008); Supriyanto (2012). Foods high in protein can increase and maintain albumin levels and minimize the possibility of decreasing albumin levels. Medical therapy can also be done by parenteral, parenteral administration such as intravenous serum albumin but the medical therapy needs several considerations such as high reative prices and their use and restrictions on use based on the severity or low levels of the albumin of the patient. This should also be noted in the use of serum albumin is the duration of albumin should not be more than 4 hours after the packaging is opened. Because it is related to the stability of available albumin which must be used for 4 hours because it is easily coagulated by heat (Syarifah, 2015).

One of the goals of giving toman fish extract is as a dietary therapy because toman fish extract is a high protein food, so it can help to increase and maintain albumin level in the blood and minimize the decreasing of albumin level in the blood.

Based on the results of research that uses alternative sources of albumin in fish other than cork fish (ikan gabus), the albumin detection method and the DNA mitochondrial gene approach Nugroho, (2016). A number of fish tested in the research results estimate that toman fish and betutu fish have the potential to be an alternative source of albumin. In Irwanda's study (2015). Test the wound healing effect of cuts in male rats has been done and given toman fish extract at a dose of $15.7 \mathrm{~mL} / \mathrm{kg} \mathrm{BW}$ of 
rats in the first group and second group was given a dose of $3.7 \mathrm{~mL} / \mathrm{kg}$ of rat for 14 days, based on the test conducted there significant effect between albumin levels and wound healing. This is caused by toman fish containing albumin protein, globular protein, which is a protein that is often applied to improve nutritional status in hypoalbuminemia. According to Irwanda's research, 2015 in his research Toman fish extract contained as much as $19.7 \mathrm{gr} / 100 \mathrm{gr}$ protein of toman fish meat. Toman fish extract also contains high fatty acids such as omega 3 and omega 6 , water soluble vitamins (B and C) and minerals.

\section{Effects of Giving Toman Fish} (Chana Micropetes) Extract Against Increased Albumin Levels

Data of albumin levels was tested for normality, the results were normally distributed with $p>0.05$. This can be seen by the significance in the control $(\mathrm{p}=0.599)$ and in the treatment $(p=0.09)$. The results of statistical analysis with the Independent Sample Test show that the correlation between the variables of toman fish extract to increase levels of abumin. The Independent Sample Test $\mathrm{t}$ value test showed its significance was 0,000 $(<0.05)$ so that there was an effect of toman fish extract administration on increasing albumin levels in mice.

The use of animals or parts of animals is one of the alternative ingredients in medical therapy that has not yet developed, even though in terms of natural resources, especially Indonesian waters, it is very potential if it is developed into a source of material in medical therapy. Utilization of marine animals and river animals as a treatment material is still in the development stage, for example the use of fish as a therapeutic treatment material such as toman fish (Chana Micropeltes). The content contained in toman fish is omega 3 with EPA $0.32 \% \mathrm{BW}$ and DHA $1.43 \%$ BW and omega $910.33 \%$ BW, if added to the total fatty acids contained in the fish meat is $63.08 \% \mathrm{BW}$. Amino acid content in toman fish is $18.89 \%$. One of the aims of giving toman fish extract is as a dietary therapy because toman fish extract is a high protein food, compared to fish in general having high protein content with protein that is easy to digest and absorbed by the body. In toman fish meat there is albumin protein that is, globular protein which is often applied clinically for nutritional improvement in those experiencing hypoalbumin (Singgih, 2012).

Based on Aliya's research results (2015); Robert et al. (2014) who sought alternative sources of albumin in fish other than cork fish (ikan gabus), using the albumin detection method and the mitochondrial DNA gene approach. Based on the results of the study stated a number of fish in the test results estimated that toman fish and betutu fish have the potential to be an alternative source of albumin. In Irwanda's research (2015) Test the healing effect of cut wounds in male rats was performed and toman fish extract was given at a dose of $15.7 \mathrm{~mL} / \mathrm{kg}$ body weight in the first group and the second group was given a dose of $3.7 \mathrm{~mL} / \mathrm{kg}$ body weight in mice for 14 days, based on tests conducted there was a significant effect between albumin levels and wound healing. This is caused by toman fish containing albumin protein, globular protein, which is a protein that is often applied to improve nutritional status in hypoalbuminemia. According to Festi 
(2018) that the nutritional value of animal protein especially toman fish can increase albumin levels. Lack of albumin in the blood will have an impact on nutrients that cannot be circulated throughout the body. Albumin substances also function to maintain fluid balance in the body. If the condition of body fluids is lacking, then the protein that enters the body will rupture so that it cannot function normally. Other studies that explain the administration of albumin in patients with hypoalbumin kidney failure require collaborative action to obtain outcame therapy, for that toman fish extract can be a good alternative consumption in patients with hypoalbumin (Syarifah, 2015). Research that also improves the quality of toman fish extract according to (Fitriyani \& Deviarni, 2018) that toman fish extract can be processed in the form of powder whose albumin content has a higher value as well as protein and fat content so that it greatly increases the body's albumin levels. .

\section{CONCLUSION}

Albumin levels before being given toman fish extract (Chana Micropetes) mostly entered in the category Hypoalbumin. Albumin levels after being given toman fish extract (Chana Micropetes) mostly increased albumin levels so that albumin levels became normal. So there is an effect of giving toman fish extract in the treatment group, to increase albumin levels in mice. Giving toman fish can be used as an alternative food that can increase albumin

\section{REFERENCE}

Aliya, Sari, A. (2015). Pengaruh Ekstrak Albumin Ikan Gabus (Chana Satriasa) Terhadap Berat Badan Pasien Tuberculosis Paru Pengobatan Fase Infasif. Skripsi. Fakultas Kedokteran Universitas Jember.

Ackland, P. (2013). Management of Chronic Kidney Disease, in : D.goldsmith S. Jayawardene.

Festi, P., W.(2018). Gizi dan Diet. Surabaya. UMSurabaya Publishing.

Fitriyani, E \& Deviarni, M., I. (2018) Pengaruh Suhu dan Waktu Ekstraksi Ikan Toman (Channa micropeltes) Menjadi serbuk Albumin. Jurnal galung Tropika. 7(2). ISSN Online 2407-6279, ISN Cetak 23024178.

Gatta A. V. (2012) Hypoalbuminemia. Intern Emerg Med

Guyton, A.C and Hall, J.E., (2016). Glomerular Filtration, Renal Blood Flow, and Their Control. In: Guyton, A.C and Hall, J.E. Texbook of Medical Physiology, ED 11 th Philadelphia: Elsevier Saunders Inc

Hasan Irsan Anggraini T., (2008). Peran Albumin dalam Penatalaksanaan Sirois Hati. Divisi Hepatologi, Departemen Ilmu Penyakit Dalam FKUI/RSCM -Jakarta.

Irwanda, W. (2015). Uji Efektifitas Penyembuhan Luka Fase Air Ekstrak Ikan Toman (Chana Micropeltes) Pada Tikus Putih Jantan Wistar Yang diberi luka Sayat. Skripsi Program Studi Farmasi Kedokteran. Universitas Tanjung Pura. 
Kusumawati. (2009). Bersahabat Dengan Hewan Coba. Yogyakarta. Universitas Gadjah Mada Pers.

Nugroho, A.Y. (2016). Perbandingan Efektifitas Terapi Albumin Ekstrak Ikan Gabus Murni Dibandingkan Human Albumin 20\% Terhadap Kadar Albumin Dan pH Darah Pasien Hipoalbuminmia. Tesis Program studi Kedokteran Keluaraga Ilmu Biomedik.

Nursalam. (2017). Metodelogi Penelitian Ilmu Keperawatan. Edisi 4. Salemba Medika. Jakarta.

Syarifah. (2015). Studi Penggunaan Albumin pada Pasien Penyakit Ginjal Kronik (PGK), Thesis, Universitas Airlangga;

Singgih, B.U. (2012). Kandungan Gizi Dan Logam Berat Pada Ikan Rawa Di Perairan Rawa Kabupaten Tanah Laut Kalimantan Selatan. Skipsi. Program Studi

Tekhnologi Hasil Perairan Fakultas perikanan dan Ilmu Kelautan Insitut Pertanian Bogor.
Supriyanto. (2012). Pengaruh Suplementasi Medosco Putih Telur terhadap Perubahan Kadar Albumin pada Pasien Bedah dengan Hypoalbuminemia. RSUP Dr. Kariadi Semarang 1 (2): 130-133.

Standar Nasional Indonesia, 2006. SNI 2354.3-2006 Cara uji kimiaBagian 2 : Penentu kadar lemak pada produk perikanan, Jakarta: Badan Standarisasi Nasional.

Standar Nasional Indonesia, 2006. SNI 2354.3-2006 Cara uji kimiaBagian 2 : Penentu kadar protein pada produk perikanan, Jakarta: Badan Standarisasi Nasional.

Standar Nasional Indonesia, 2011. SNI 2346-2011 tentang petunjuk pengujian Organoleptik dan atau Sensori Jakarta: Badan Standarisasi Nasional.

Robert K, David A, Peter J, Victor W. (2014). Biokimia Harper. Jakarta. Edisi 29. EGC- Penerbit Buku Kedeokteran. 